\title{
Örgütlerde Dönüşümcü Liderlik ve Performans İlişkisinin Değişim Mühendisliği Aracı Rolünde İncelenmesi: İmalat Sanayii Örneği
}

DOI: $10.26466 /$ opus.684573

\author{
Berk Küçükaltan* - Gözde Mert ** \\ * Dr. Öğr. Üyesi, Trakya Üniversitesi, Uygulamalı Bilimler Fakültesi, Edirne/Türkiye \\ E-Posta: berkkucukaltan@trakya.edu.tr ORCID: 0000-0002-2766-3248 \\ ** Dr. Öğr. Üyesi, Nişantaşı Üniversitesi, İ.̇̇.S.B.F, İstanbul/Türkiye \\ E-Posta: gozde.mert@nisantasi.edu.tr \\ ORCID: 0000-0002-9314-0242
}

$\ddot{O} z$

Dinamik yapıdaki zorlu rekabetçi koşullarda her ne kadar farklı parametreler mevcut olsa da, örgütleri başarıya ulaştıracak ve devamlılığını să̆layacak faktörler daha ön plana çıkmaktadır. Bu faktörler arasında, örgütlerin akıbetini etkileyebilecek özelliklerde olan, gerektiğinde değişimin öncülü̈̆̈̈nü yaparak örgütlerin karar mekanizmalarında rol alan liderler önem arz etmektedir. Diğer yandan, işletmelerin başarısında etkili bir başka faktör olan performans göstergelerinin ölçülmesi ve yenilenmesi, örgütlerin değişen durumlara göre farklı stratejik yaklaşımları uygulayabilmeleri ve hayatta kalabilmeleri açısından kritik önem taşımaktadır. Dolayısıyla, işletmeler değişen dünya koşullarına ayak uydurup daha rekabetçi olabilmek adına, faaliyetlerinde ve stratejilerinde düzenli olarak dönüşüme ve yeniliğe gitmek durumundadırlar. Tüm bunlardan hareketle, bu araştırmada, dinamik altyapının beraberinde getirdiğ $i$ radikal dönüşüm ve süreç odaklı anlayışı içinde barındıran değişim mühendisliği kavramının aracı rolünde, çalışanlarda motivasyon yaratıp işe teşvik eden ve değişime önem veren dönüşümcü liderlik kavramı ile örgüt performansı arasındaki ilişki imalat sanayiinde incelenmektedir. Bu doğrultuda, mevcut ilişkilerin varlığı ve anlamlılıkları, İstanbul'da imalat sanayiinde çalışan 390 kişiye uygulanan anket tekniği yardımıyla araştırılmıştır. Elde edilen bulgular, değişim mühendisliğinin, dönüşümcü liderlik ve performans arasındaki ilişkide kısmi ara değiş̧en etkisine sahip olduğunu ortaya koymuştur. Böylece, araştırma, bu üç kavramın ilişkisinin göz ardı edildiği akademik yazına katkı sağlamanın yanı sıra, iş hayatında çalışan profesyonellere ve kural koyuculara da gerek davranışsal boyutlar açısından gerekse de sonuç odaklı yaklaşım içinde başarı faktörlerinin ilişkilerini ortaya koyması bakımından yol gösterici niteliğe sahiptir.

Anahtar Kelimeler: Değişim Mühendisliği, Dönüşümcü Liderlik, İmalat Sektörü, Örgüt Performansi 


\title{
Examining the Relationship between Transformational Leadership and Performance in Organisations with the Mediating Role of Reengineering: The Case of a Manufacturing Industry
}

\begin{abstract}
Despite the existence of different parameters in the dynamic and compelling competitive conditions, the factors which lead organisations to the success and enable them to maintain their continuity come to the forefront. Among these factors, the leaders who have the characteristics of affecting the aftermath of organisations and take part in decision mechanisms of organisations by leading them in changes, when needed, are of great importance. On the other hand, measurement and modernisation of performance indicators, which is another influential factor for the success of businesses, is also critical for organisations to perform different strategic approaches in accordance with changing conditions and to survive. Accordingly, in order to keep up with the changing conditions and to become more competitive, businesses need to change and innovate their activities and strategies regularly. From these points forth, in this research, the relationship between the transformational leadership, which stimulates employees to work by creating motivation and gives importance to the change, and organisational performance is examined in the manufacturing industry with the mediating role of the reengineering concept, which inherently incorporates the radical transformation brought by the dynamic infrastructure and processoriented understanding. In line with these, the existence of the relationships between these concepts and their significance are investigated through the questionnaire technique applied to 390 respondents working in the manufacturing industry in Istanbul. The obtained findings revealed that the reengineering variable has a partial mediating effect on the relationship between transformational leadership and performance. Thus, the research contributes not only to the academic field where the relationships among these three concepts are unexplored, but also both to practitioners and to policy-makers in terms of exhibiting the relationships of these success factors from the aspects of behavioural dimensions and the results-oriented approach.
\end{abstract}

Keywords: Reengineering, Transformational Leadership, Manufacturing Industry, Organisation Performance 


\section{Giriş}

Örgütler, akademik yazında ve pratik hayatta her ne kadar farklı tanımlansalar da, faaliyetlerini yürütme amaçları dolayısıyla temel olarak iki ana başlık altında toplanabilmektedirler. Bunlardan ilki kâr elde ederek rekabetçiliklerini ve pazar paylarını arttırma gayreti içerisinde olan kâr amaçlı örgütler, diğeri ise kâr elde etmekten ziyade belirli bir misyon üstlenerek toplumsal fayda sağlamayı temel gaye haline getiren kâr amacı gütmeyen örgütlerdir (Çetin, 2012; Küçükaltan, 2018). Bu araştırmada, mevcut literatür ve araştırma sorunsalı dikkate alınarak, iki farklı amaç arasından kâr amacı güden örgütler odak noktası haline getirilerek incelenmekte, böylece örgütlerin girdileri, süreçleri ve çıktıları arasında değerlendirilen kavramlar bu kapsamda ele alınmaktadır. Dolayısıyla, bu araştırmada ifade edilen örgüt kavramı kâr amaçlı örgütleri karşlamaktadır.

Günümüz endüstri çağında, örgütler rekabet avantajı elde ederek bu avantajı sürdürülebilir hale getirmek için örgütsel kültür, bilgi teknolojileri, insan sermayesi, liderlik gibi örgüt bütününde ele alınabilecek stratejik faktörlere ihtiyaç duymakta, böylece hem yapısal sermaye hem de insan sermayesinin birleştirilmesini hedeflemektedirler (Birasnav vd., 2010). Örgütler bunu yaparken, endüstride ve ticaret alanı içerisinde pozisyonları için kritik önem arz eden kabiliyet yönetimi ve performans süreçleri gibi konularda da güncelleştirmeler ve gelişmeler gerçekleştirmektedirler (Parnaby ve Towill, 2009). Bu gelişmeler kapsamında örgütlerin işleyişinde stratejik öneme sahip olan liderlik türleri büyük oranda araştırmalara konu olmaktadır. Özellikle son yirmi yıllık dönem dikkate alındığında, dönüşümcü liderlik türünün çalışan davranışına olan etkisinin araştırmacılar tarafından yoğun olarak incelendiği ve dönüşümcü liderliğin iş performansı ile örgütsel bağllıı gibi çıtıya yönelik kriterlerle pozitif ilişkili olduğu görülmektedir (Miao vd., 2012).

Her ne kadar örgütsel süreçlere ve stratejik faktörlere dair bu denli olumlu gelişmeler ve deneyimler yaşansa da, bu kavramlar dahilinde mevcut literatür incelendiğinde akademik yazında bazı boşlukların da yer aldığı gözlemlenmektedir. Örneğin, dönüşümcü liderlik örgütler için önemli bir stratejik unsur olarak tartışılsa da, Miao vd.'nin (2012) yer verdiği gibi, dönüşümcü liderliğe ilişkin yapılan araştırmalar genellikle batılı örgütler içerisinde sınırlı kalmaktadır. Ayrıca, dönüşümcü liderliğin tam olarak genel kabul görmüş 
bir tanımı yapılamadığından, kavramsal kapsam açısından da bazı belirsizlikler mevcuttur. Benzer şekilde, örgütsel performans açısından konu ele alındığında, örgütsel performansı tanımlamak kadar, ölçmek de zor olabilmektedir (Hussein vd., 2014). Bu hususta örgütsel performansı ölçmek için kısa veya orta vadeli bakış açısı kazandıran finansal verilerin tek başına yeterli olamayacağı aşikârdır. Bu nedenle, finansal kriterler kadar finansal olmayan kriterler de örgütsel performans ölçümünde düşünülmektedir. Dolayısıyla, Wan Zakaria ve Ilias (2016)'ın da özetlediği gibi, örgütsel performans için operasyonel performans, kârlllıktaki iyileşme, örgütsel ve iş süreçlerindeki iyileşme, belirlenen hedeflere ulaşma gibi ölçütler örnek olarak kullanılabilir. Ancak, unutulmamalıdır ki, örgütsel performansta iyileşme ve yenilik yaşanabilmesi için, süreçlerde ve sistemsel yapılarda bazı değişimler meydana gelmeli, bu sayede imalat sanayiinin öncülük ettiği değişim mühendisliği kavramına önem verilmelidir (Chan ve Jiang, 2001). Bu durum aslında, değişim mühendisliğinin ve bu anlayışı benimseyebilecek dönüşümcü liderlerin örgütler için kritik birer stratejik unsur olduğunu göstererek, örgüt performansının bu ölçütlerden etkilenebileceğini ortaya koymaktadır.

Böylelikle, buraya kadar bahsi geçen akademik boşluklar ve motivasyonlar dahilinde, imalat sanayiine yönelik olan mevcut araştırma, dönüşümcü liderlik, değişim mühendisliği ve örgüt performansından oluşan bir model içermekte ve örgütlerin stratejisinde önem arz eden bu üç kavramın birbirleriyle olan etkileşimini göz önünde bulundurarak şu soruların yanıtlarını aramayı amaçlamaktadır:

- Dönüşümcü liderlik örgüt performansını nasıl etkilemektedir?

- Dönüşümcü liderliğin örgüt performansını etkilerken değişim mühendisliğinin aracı rolünün anlamlı bir ilişkisi var mıdır?

$\mathrm{Bu}$ araştırma soruları ve belirlenen amaç doğrultusunda, mevcut araştırma şu şekilde tasarlanmıştır. Çalışmada öncelikle bu üç kavramın imalat sanayii bağlamında tartışıldığ çalışmalara değinilmiştir. Sonraki aşamada, akademik yazın doğrultusunda araştırma modeli ve hipotezler oluşturulmuş; uygulanan metodolojiye, araştırmanın ampirik uygulamadaki analizlerine ve bulgularına yer verilmiştir. Makalenin son bölümünde elde edilen bulgular kapsamında araştırmanın ortaya koyduğu akademik ve pratik katkılar ifade edilmiş, gelecek çalışmalar için de bazı önerilerde bulunulmuştur. 


\section{Literatür Araştırması}

Bu araştırmada, imalat sanayii bağlamında dönüşümcü liderlik, değişim mühendisliği ve örgüt performansı ilişkilerinin incelenmesi amaçlandığı için, mevcut akademik yazını kapsamlı irdeleyebilmek adına literatür araştırmasında bu kavramların farklı kombinasyonlarından oluşan anahtar kelime çiftlerinden yararlanılmıştır. Belirlenen anahtar kelimeler, öncelikle akademik çalışmalarda sıklıkla kullanılan ScienceDirect ve Scopus veritabanlarında özet, başlık, anahtar kelimeler kapsamındaki makaleler içerisinde (basım aşamasındaki makaleler seçeneği dahil edilerek) aratılmış ve ortaya çıkan 15 makaleden ancak 11'ine erişim sağlanmıştır. Ek olarak, akademik veri tabanı kullanımının yanı sıra, bu iki veritabanında çıkmayan ancak incelenmesi önemli sayılabilecek çalışmaları gözden kaçırmamak adına, çapraz referans yöntemi de Kucukaltan vd.'nin (2016) de benzer şekilde gerçekleştirdiği gibi ayrıca uygulanmış ve Google Akademik'den de yararlanılarak ilgili çalışmalar literatür araştırması kapsamına dahil edilmiştir.

$\mathrm{Bu}$ aşamalar sonrasında, mevcut araştırma modelindeki üç kavram dikkate alındığında, imalat odaklı incelenen literatürde dönüşümcü liderlik ve performans ilişkisinin değişim mühendisliğine göre daha fazla ele alındığı görülmektedir. Dönüşümcü liderlik ve performansa dair çalışmaların yer aldığ literatür genel ve ilişkisel özel olmak üzere ikiye ayrılmaktadır. Genel düzeyde, Bay ve Akpınar'ın (2017) liderlik tarzları ile girişimcilik özellikleri arasındaki ilişkiyi araştırdığı çalışmasında dönüşümcü liderlik türü ve ortaya çıkışı tanıtılmıştır. İlişkisel özel düzeyde ise, literatürün daha detaylı araştırıldığ1 gözlemlenmekte ve çalışmalarda, dönüşümcü liderliğin insani sermayeye dayalı iş performansı, örgüt performansı ve örgüt sürdürülebilir performansı ile olan ilişkilerinin büyük oranda ele alındığı ortaya çıkmaktadır.

İnsani sermayeye dayalı iş performansı kapsamında, Birasnav vd. (2010) Hindistan imalat sanayiinde, geçici liderlik deneyimine sahip 470 orta ve üst düzey yönetici çalışan ile anket çalışması yürüterek, çalışanların liderler üzerindeki dönüşümcü özelliklerinin ve geçici liderliklerinin insani sermayeyi olumlu yönde etkileyip etkilemediğini araştırmışlar ve elde ettikleri sonuçlar dahilinde anlamlı düzeyde olumlu yönde ilişkili olduğunu saptamışlardır. Benzer bir anlayışla, Miao vd.'nin (2012) çalışmasında, çalışanın dönüşümcü liderlik davranışı algısı ile çalışma çıtısı arasındaki ilişki üzerinde lider ile özdeşleşmenin aracı etkisi araştırılmıştır. Güneydoğu Çin'de yer alan büyük 
ölçekli bir giysi imalat işletmesinde çalışan göçmen işçiler ve onların amirlerinden toplanan anket verilerine göre, dönüşümcü liderlik duygusal iş bağlllığına ve iş performansına olumlu etki ederken, bu tür liderliğin personeldeki devir niyetine olumsuz etki ettiği belirlenmiştir. Çalışmada ayrıca dönüşümcü liderliğin inovatif (yenilikçi) davranış üzerinde anlamlı bir etkisi olmadığı da saptanmış, lider ile özdeşleşmenin de dönüşümcü liderlik ile çalışan davranışı arasında mediator (aracı) rolü oynadığı, ancak aynı rolün dönüşümcü liderlik ile iş performansı arasında sergilenmediği de vurgulanmıştir.

Dönüşümcü liderliğin örgüt performansı ile olan ilişkisi kapsamında, Ardichvili ve Gasparishvili'nin (2001) eski Sovyetler Birliği'nde yer alan dört ülkedeki (Kırgizistan, Kazakistan, Gürcistan ve Rusya) imalat sanayiinde faaliyet gösteren dokuz firma üzerinde yaptığı anket çalışmasında, 2391 yönetici ve çalışan ile görüşülerek farklı liderlik tarzları ile örgüt performansı arasındaki ilişki incelenmiştir. Dört ülkedeki anket sonuçları, dönüşümcü tarzlara yönelik net bir tercihin olmadığını, dönüşümcü ve işe yönelik liderliğin açık bir tercih şeklinde kullanılmadığını göstermiştir. Performansa dair ise, çalışmada, koşullu ödüllendirmenin örgüt performansı ile üst düzeyde olumlu ilişkisinin bulunduğu, istisnalarla yönetim ile örgüt performansı arasında da yine olumlu ilişki bulunduğu ve bunların yanı sıra, liderlik tarzları arasında da anlamlı farklılıklar olduğu ifade edilmiştir.

Örgüt performansının sürdürülebilirlik ile birleştirildiği sürdürülebilir performans kapsamında, Burawat (2017) dönüşümcü liderlik, yalın üretim ve sürdürülebilir performans arasındaki ilişkileri Tayland imalat sanayiinde KOBİ olarak faaliyet yürüten örgütlerdeki orta ve üst düzey yöneticiler kapsamında incelemiştir. Karma metot uygulanan çalışmada, nicel açıdan anket yöntemi uygulanmış ve 598 kişiden toplanan anket sonuçlarında, dönüşümcü liderliğin yalın üretim ve sürdürülebilir performans ile olan ilişkisinin yanı sıra, yalın üretimin de sürdürülebilir performans ile olan ilişkisi saptanmış ve hatta, yalın üretimin dönüşümcü liderlik ve sürdürülebilir performans arası ilişkideki kısmi mediator (aracı) rolü de belirtilmiştir. Araştırmanın 40 katılımcı ile derinlemesine görüşme yapıldığı nitel kısmında ise, yalın pratiklerin aslında otomotiv sektörü için uygun olduğu, diğer sektörlerde bu pratiklerin daha az uygulama yeri olduğu belirtilmiştir. Yazarın daha güncel olan benzer bir diğer çalışmasında ise, Burawat (2019) aynı değişkenlere sür- 
dürülebilir liderlik değişkeni de ekleyerek yine aynı endüstride aynı metodolojik yaklaşımla aynı sayıdaki katılımclara ulaşmıştır. Çalışmanın önceki çalışmadan farklı olarak bulgularında, yalın üretimin sürdürülebilir liderlik ve sürdürülebilir performans arasındaki ilişkide de kısmi aracı rolü vurgulanmıştır.

Diğer yandan, göreceli olarak daha sınırlı sayıda tartışılan değişim mühendisliğine ilişkin çalışmalara bakıldığında, Chan ve Jiang (2001), işletme süreç değişim mühendisliğini esnek üretim sistem tasarımı, analizi ve teknolojisi açısından ele alarak en iyi tasarımı bulmayı amaçlamışlardır. Bu doğrultuda, araştırmacilar konuyu bir üretim şirketi özelinde değerlendirerek, uygulamalarını uzman görüşü, Analitik Hiyerarşi Süreci ve yapay zekada yer alan bulanık mantık ve sinir ağları gibi yaklaşımlardan yararlanarak yapmışlardır. Başka bir çalışmada, Eltantawyy vd. (2015) tedarik zinciri içerisinde imalat sanayiinde faaliyet gösteren üç basamak için (müşteri, ilk sıra tedarikçi, ikinci sıra tedarikçi) fiziksel ve bilgi akışlı koordinasyonun tedarik zinciri verimliliğinde iyileşmeye neden olup olamayacağın eylem araştırması aracılığıyla kantitatif ve kalitatif teknikler yardımıyla araştırarak, süreç değişim mühendisliği için koordinasyonun önemi üzerinde durmuşlardır.

Değişim mühendisliğinin performans ile ilişkilendirildiği bazı çalışmalar da literatürde mevcuttur. Örneğin, Parnaby ve Towill (2009) üretim aktivitelerinde, bilhassa öğrenen organizasyon ve değişim yönetimi süreçlerinde, projelerle yönetim (managing-by-projects) konseptinin önemine dikkat çekerek, bu konseptin uluslararası örgütlerin rekabetçiliklerine ve performanslarına olumlu yansımalarını vurgulamışlardır. Benzer şekilde, Feibert vd. (2019) hastanelerde lojistik süreç performansının iyileştirilmesi üzerinde durarak imalat sanayiindeki yalın faaliyetlerin ve değişim mühendisliğinin sağlık sektöründe kullanımına ilişkin Danimarka ve Amerika hastanesi karşılaştırmasına dayalı karma metot seçiminin kullanıldığı bir araştırma yürütmüşlerdir.

Literatürde bu kavramlar çerçevesinde ortaya çıkan çalışmalar bütünsel açıdan ele alındığında, dönüşümcü liderliğin, değişim mühendisliğinin ve örgüt performansının etkileşim içerisinde olduğu görülebilmektedir. Bu anlamda, konunun daha detaylı ele alınarak incelenmesi ve ilişkilerin anlamlı seviyelerde olup olmadığının irdelenmesi için, mevcut araştırma soruları ve araştırma amacı göz önünde bulundurularak, bir sonraki bölümde değinilecek olan araştırma modeline ihtiyaç duyulmaktadır. 


\section{Araştırma Modeli ve Hipotezler}

\section{Örgütlerde Dönüşümcü Liderlik ve Değişim Mühendisliği İlişkisi}

Lider ile yönetici, sosyal hayatta oldukça fazla karıştırılan iki kavramdır. Bu iki kavramın ayırt edilmesini sağlayan en önemli özelliklerden biri, liderin önderlik niteliklerine sahip olmasıdır. Liderlerde bulunan özelliklerin farkl1laşmasıyla veya bazı özelliklerin daha belirgin hale gelmesiyle, farklı liderlik türleri ortaya çıkmış, özellikle son yıllarda akademik yazında oldukça sık karşılaşılan dönüşümcü liderlik de bunlardan biri olmuştur.

Dönüşümcü liderlik, Bass ve arkadaşları tarafından resmileştirilip popüler hale getirilen, değişim ve reformu vurgulayan bir liderlik türüdür. Dönüşümcü liderlik, astların kendilerinden ödün vermelerini, zor amaçlarda bile örgüte bağlılıklarını, beklenenden daha fazlasını vermeye çalışmalarını vurgularken, çalışanların ortak misyon ve vizyon ile daha ileri aşamadaki toplu amaca ulaşmasını da içinde barındırmaktadır (Ardichvili ve Gasparishvili, 2001). Karşlıklı etkileşimin önemli olduğu bu liderlik türünde, dönüşümcü liderler bir yandan statükonun değişimine odaklanarak örgütün yapısının ve statüsünün değişimi üzerinde dururlarken, diğer yandan da vizyoner profil çizerek astlar için rol model özelliği taşımakta ve onlarda entelektüel uyarıma neden olmaktadırlar (Bay ve Akpınar, 2017). Diğer bir deyişle, dönüşümcü liderler adeta sosyal mimarlar gibi davranarak organizasyon değerlerinin iletişimle yansitılmasında ve dönüştürülmesinde önemli rol üstlenmektedirler (Burawat, 2017).

Çok boyutlu bir liderlik türü olarak görülen dönüşümcü liderlik, değişimin öncülüğünü yapma konusunda da oldukça etkindir (Burawat, 2019). Zaten, örgüt ve çalışan değerlerinde yaratılan bu değişim ve sahip olunan inovatif bakış açısı da rekabetçi avantaja erişmede gerekli unsurlardır (Birasnav vd., 2010). Bu hususta, günümüzde yaşanan değişimler ve gelişmeler düşünüldügünde, örgütlerde yaşanan problemlerin yalnızca belirli metotlar ile çözülebileceği anlayışı artık kaybolmakta, dolayısıyla karmaşık ve girift ilişkilerin olduğu işletme ekosisteminde çözümlerin sürekli değişim, sürekli öğrenme gibi güncel kavramların veya uygulamaların aracılığıyla olabileceğine vurgu yapılmaktadır (Nişancı, 2015). Bu anlamda, değişim mühendisliğinin önemi de örgütlerin rekabetçi kalmasında ve bu rekabetlerinin sürdürülebilir hale gelmesinde daha belirgin ortaya çıkmaktadır. 
Değişim mühendisliği İngilizce "reengineering" olarak adlandırılmakta, değişim mühendisliğinden etkilenen alanlar ise genel itibariyle insan, süreç ve teknoloji olarak gruplandırılmaktadır. Bu gruplar çerçevesinde, dönüşümcü liderlerin hem insan sermayesinde hem de süreçlerde değişim yarattığı (Birasnav vd., 2010), bunu yaparken de inovatif bakış açısını benimsediği dikkate alındığında, hem dönüşümcü liderliğin hem de değişim mühendisliğinin bu kapsamda ilişkili olduğu düşünülebilmektedir. Dolayısıyla, bu iki kavram için mevcut araştırmada belirlenen hipotez şu şekilde önerilmektedir:

- Hı: Dönüşümcü liderlik değişim mühendisliğini etkilemektedir.

\section{Örgütlerde Değişim Mühendisliği ve Örgüt Performansı İlişkisi}

Değişim mühendisliği kapsam olarak, örgütlerdeki tüm süreçlerin ve bu süreçlerle beraber çalışan tüm sistemlerin yeniden yapılandırıldığı radikal değişimi ifade etmektedir (Nişanc1, 2015). Radikal değişim derken tüm organizasyon ve organizasyonun ilişkili olduğu direkt ve endirekt aktörler de bu kapsama dahil edilmektedir (Chan ve Jiang, 2001). Örneğin, küresel olarak yaşanan gelişmeler, bir yandan yeni ihtiyaçların doğmasına ve yeni pazarların oluşmasına sebebiyet verirken, diğer yandan müşteri beklentilerinde de değişime ve çeşitliliğe neden olmaktadır (Pado, 2017). Buradan hareketle, işletmelerin tecrübe ettiği değişimlere bütünsel bakarak, tedarik zinciri yapısında bulunan tüm bileşenleri değişim mühendisliği anlamında kapsamlı olarak değerlendirmek gerekmektedir.

Değişim mühendisliğine ilişkin her ne kadar tanımlamalar literatürde farklılık gösterse de, Yavas ve Yasin (2001) değişim mühendisliğini, operasyonel ve müşteri odaklı performans çıktılarını (maliyet, kalite, tatmin, hız gibi) arttırmak için içerik, kapsam, akış ve görev/alt görev yapılarının yeniden tasarlanması şeklinde ifade etmişlerdir. Bir diğer ifadeyle, değişim mühendisliğinin temel amacl, örgütlerin belirlemiş olduğu performans göstergelerinde olumlu bir yansıma oluşturarak işletmede iyileştirmeye sebebiyet vermektir. Yani, örgütsel performansta yenilik ve iyileşme yaşanabilmesi için, süreçlerde (teknik ve kültürel boyutlar dahil), sistemlerde, politikalarda ve yapılarda uygulanan değişim mühendisliğine ihtiyaç vardır (Chan ve Ji- 
ang, 2001). Dolayısıyla, değişim mühendisliği ve örgüt performansı arasındaki ilişki için mevcut araştırmada belirlenen hipotez şu şekilde önerilmektedir:

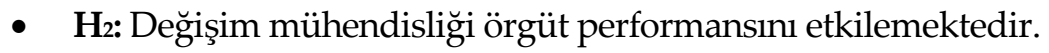

\section{Örgütlerde Dönüşümcü Liderlik ve Örgüt Performansı İlişkisi}

Dönüşümcü liderlik türünün benimsenmesi, örgütlerde farklı kazanımlara yol açarak direkt ve/veya endirekt olarak örgütlerin performansına etki edebilmektedir. Bu hususta, Bass'in (1985) dönüşümcü liderlik için vurgulamış olduğu dört temel bileşen (idealleştirilmiş etki, ilham yaratıc motivasyon, entellektüel teşvik, bireyselleştirilmiş düşünce) (Miao vd., 2012), çalışanların potansiyelinin ortaya çıkarılarak performanslarını anlamlı düzeyde etkileyen, bu sayede dolaylı olarak da örgütlerde yatırım geri dönüş oranının yükselmesini sağlayan unsurlar olarak gösterilmektedir (Birasnav vd., 2010). Yani, dönüşümcü liderler, vizyon oluştururken katılımcıllğı da vurgulayarak vizyonun paylaşılmasını sağlarken, örgütün başarılı olmasına ve performansının artmasına neden olmaktadırlar (Mert vd., 2019).

Örgüt performansının tanımı yapılmak istendiğinde, akademik yazında bu anlamda genel kabul görmüş belirli bir tanımın olmadığı, araştırılmak istenen konuya göre farklılık gösterebilecek tanımlamaların literatürde mevcut olduğu görülmektedir. Örneğin, yetenek yönetimi alanında örgütsel performans için yüksek performans gösterebilen yetenekli bireylerin başarısı dikkate alınırken (Gangula, 2016), sürdürülebilir performans açısından tüm ekonomik, sosyal, çevresel faktörlerin yanı sıra, tek bir örgüt sınırının ötesine geçerek tedarik zinciri içerisinde yer alan tüm aktörlerin dahil edildiği faktörler kümesi değerlendirilmektedir (Burawat, 2019).

Dönüşümcü liderlik kapsamı için temel olarak, organizasyonel ve operasyonel düzeyde değişimlerin yönetildiği ve bu değişimlerin örgüt içerisine yerleştirildiği, ekonomik ve çevresel düzeyde karmaşı bir düzenin organize edildiği, sosyal düzeyde ise insan sermayesine katkı yapıldığı düşünüldügünde, dönüşümcü liderliğin sonuç itibariyle örgüt performansını iyileştirdiği yorumlanmaktadır (Birasnav vd., 2010). Dolayısıyla, bu araştırmada dönüşümcü liderlik ile örgüt performansı arasındaki direkt ilişkiye dair hipotez şu şekilde önerilmektedir: 
- $\quad \mathbf{H}_{3}$ : Dönüşümcü liderlik örgüt performansını direkt olarak etkilemektedir.

Böylesi direkt ilişkinin yanı sıra, değişim mühendisliği aracilığında dönüşümcü liderlik ve örgüt performansı arasında endirekt ilişki olabileceği de düşünülmektedir. Dolayısıyla, araştırma modelini de ifade eden bir diğer hipotez şu şekilde önerilmektedir:

- Ha: Değişim mühendisliği, dönüşümcü liderlik ve örgüt performansı arasında ara değişkendir.

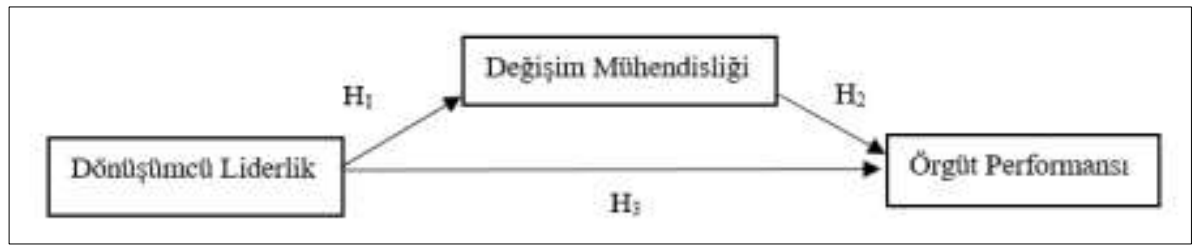

Şekil 1. Araştırma Modeli

Literatürde mevcut bulunan çalışmalar ve araştırmanın yanıt aradığı sorular kapsamında oluşturulan hipotezler dikkate alınarak, araştırmanın modeli Şekil 1'deki gibi tasarlanmıştır. Böylece, model aracilığıyla araştırmaya konu olan kavramlar arası ilişkilerin anlamlılık düzeylerinin imalat sanayii için tespit edilmesi amaçlanmaktadır.

\section{Araştırma Yöntemi}

Araştırmanın amacı nicel veri analizi yardımıyla mevcut ilişkilerin varlığının ampirik olarak incelenmesi olduğundan dolayı, Saunders vd.'nin (2009) de ifade ettiği gibi pozitivist felsefe benimsenerek tümdengelim yaklaşımından yararlanılmıştır. Bu felsefe ve yaklaşım temel alındığında, büyük miktardaki verilerin analizinde (Fleming ve Meakin, 2004) ve teoriye dayalı olarak oluşturulan hipotez testlerinin incelenmesindeki kullanımından dolayı (Afonina, 2015) nicel yöntemler arasında bulunan anket tekniği bu araştırmada uygulanmıştır. Ayrıca, anket tekniği uygulanırken, cevaplama oranını artırabilmek, zamanında yanıt alabilmek, sorulara ilişkin oluşabilecek tereddütleri gidermek amaciyla yanitlayanlarla yüzyüze görüşme tercih edilmiştir.

Anket tekniğinin uygulanmasında, araştırmanın ve anket sorularının geçerlilik ve güvenirliklerine de dikkat edilmiştir. Bu hususta, içerik geçerliliği 
öncelikle uygulanarak soruların uygunluğu, yeterli kapsama sahip olup olmadığı ve ölçülmek isteneni ölçüp ölçmediği araştırılmış, sonrasında ise pilot test yapılarak sonuçların tutarlılığı irdelenmiştir (Saunders vd., 2009). Bu aşamalardan sonra soru formu nihai halini alarak, hipotez ifadelerinde yer alan ilişkilerin incelenmesine dair birincil veriler toplanmış ve analiz edilmiştir.

\section{Türkiye'de İmalat Sanayiinin Önemi}

Türkiye imalat sanayii, tarım ve hizmet sektörlerine nazaran daha yüksek emek verimliliğine sahip olduğundan, imalat sanayiindeki istihdam artışı ortalama emek üretkenliğini de arttırmakta ve bu nedenle, üretkenlik çalışmalarında en çok önem verilen sektör olarak gösterilmektedir (Polat, 2011). Nitekim, 2019 yılı ilk 10 ayı için TÜİK iş gücü istatistiklerinde yer alan "istihdam edilenlerin yıllar ve cinsiyete göre iktisadi faaliyet kolları" raporu incelendiğinde, tarım, sanayi, inşaat ve hizmetlerden oluşan dört faaliyet kolu içerisinde imalat sanayiinin, tarım, ormancılık ve balıkçlık alt kategorisi ile beraber Türkiye ekonomisinde en çok istihdama yol açtığı görülmektedir (TÜİK, 2019). Bunun yanı sıra, imalat sanayii teknolojinin yayılması anlamında da önemli bir rol üstlenmektedir. Ancak, Türkiye imalat sanayiinin sadece düşük teknoloji içerikli sektörlerde net ihracatçı, orta ve yüksek teknoloji içerikli sektörlerde ise net ithalatçı olduğu düşünüldüğünde, gelişen teknoloji politikasını destekleyecek ve sanayide derinleşmeyi sağlayacak bir dönüşümün gerçekleştirilmesinin gerekli olduğu gözlemlenmektedir (Eşiyok, 2013). Bu nedenle, arzu edilen dönüşümün gerçekleşmesinde gerekli stratejik unsurlar olan dönüşümcü liderlik, değişim mühendisliği ve örgüt performansı ilişkilerinin, imalat sanayii gibi ülke ekonomisi için bu denli kritik öneme sahip bir sanayi bağlamında incelenmesi, araştırmanın önemini ve katkı potansiyelini de ortaya koymaktadır.

\section{Araştırmanın Ölçekleri}

Araştırma modelinde bulunan bağımlı ve bağımsız değişkenlerin incelenmesi için, 5'li Likert sisteminde hazırlanan, toplam 61 ifade araştırmaya katılan kişilere yöneltilmiştir. Araştırma deseninde, araştırmaya dahil olan kişilerin demografik özellikleri için altı, firma konusundaki bilgiler için ise iki ifade bulunmaktadır. 
Araştırmada yer alan değişkenlerin içeriksel anlamda oluşturulmasında belirli ölçekler ve çalışmalar takip edilmiştir. Örneğin, dönüşümcü liderlik konusunu ölçmek amacıyla Podsakoff vd.'nin (1990) ortaya çıkardığı, İşcan'ın (2006) Türkçe'ye uyarladığı ölçek kullanılmıştır. Ölçek, toplam 23 ifade ve dört alt boyuttan oluşmaktadır. Diğer yandan, değişim mühendisliği konusunu ölçmek için Dağcl (2004), Kocakahyaoğlu (2008) ve Dokuzer'in (2006) hazırladığı ölçeklerden yararlanılmıştır. Son olarak da, örgüt performansı ölçeği için Akgün vd. (2009) tarafından hazırlanan ve 11 ifadeden oluşan ölçek kullanılmıştır. Ölçek finansal ve finansal olmayan performans olarak iki boyuttan oluşmaktadır.

\section{Araştırmanın Örneklemi}

Saha araştırmasi, Ekim 2019-Ocak 2020 tarihleri arasında İstanbul'da bulunan ve imalat sanayiinde faaliyet gösteren firma çalışanları ile gerçekleştirilmiştir. Araştırmaya toplamda 402 kişi katılmış olup, veri toplamada basit tesadüfi yöntem kullanılmıştır. Toplanan bazı anket formlarının eksik cevaplanmasından dolayı ancak 390 kişinin verileri analiz işlemlerine dahil edilebilmiştir. Tablo 1, araştırmaya dahil edilen kişilerin demografik özelliklerini göstermektedir.

Tablo 1. Araştırmaya katılan kişilere ait özellikler $(n=390)$

\begin{tabular}{|c|c|c|c|c|c|}
\hline Gruplar & Frekans & Yüzde & Gruplar & Frekans & Yüzde \\
\hline Yaş & & & Eğitim Dïzeyi & & \\
\hline $25-30$ & 38 & 9,7 & Önlisans & 117 & 30,0 \\
\hline $31-40$ & 221 & 56,7 & Lisans & 179 & 45,9 \\
\hline $41-50$ & 79 & 20,3 & YL/DR & 94 & 24,1 \\
\hline 51 ve üzeri & 52 & 13,3 & & & \\
\hline \multicolumn{3}{|c|}{ Şirket İçindeki Pozisyon Süresi } & \multicolumn{3}{|l|}{ Toplam Deneyim Süresi } \\
\hline 1 yıldan az & 53 & 13,6 & 1 yıldan az & 70 & 17,9 \\
\hline $1-5$ & 112 & 28,7 & $1-5$ & 94 & 24,1 \\
\hline $6-10$ & 132 & 33,8 & $6-10$ & 112 & 28,7 \\
\hline 11 yll ve üzeri & 93 & 23,8 & 11 yıl ve üzeri & 114 & 29,2 \\
\hline \multicolumn{6}{|l|}{ Cinsiyet } \\
\hline Kadın & 133 & 34,1 & Erkek & 257 & 65,9 \\
\hline \multicolumn{6}{|c|}{ Çalışılan Bölüm } \\
\hline Yönetim & 69 & 17,7 & Muhasebe/Finans & 76 & 19,5 \\
\hline Pazarlama & 56 & 14,4 & Üretim & 47 & 12,1 \\
\hline İK & 68 & 17,4 & Mühendislik/Tasarım & 74 & 19,0 \\
\hline
\end{tabular}


Kişilerin özellikleri incelendiğinde, katılımcıların \%65,9'unun erkek, \%34,1'inin kadın; \%56,7'sinin 31 ile 40 yaş arasında; \%45,9'unun lisans mezunu olduğu; \%33,8'inin 6 ile 10 yıldır aynı kurumda çalıştığı; \%29,2'sinin 11 yıldan daha fazla iş tecrübesine sahip olduğu ve \%19,5'inin muhasebe/finans bölümünde çalıştığı görülmektedir. Araştırmaya konu olan kişilerin çalıştıkları firmalara ilişkin bilgiler ise Tablo 2' de sunulmaktadır.

Tablo 2. Firma Bilgilerine Ait Özellikler $(n=390)$

\begin{tabular}{llllll}
\hline Gruplar & Frekans & Yüzde & Gruplar & Frekans & Yüzde \\
\hline Firma Yaşı & \multicolumn{5}{c}{ Firma Büyüklü̈̆̈̈̈ } \\
\hline 1 yıldan az & 4 & 1,0 & Küçük & 90 & 23,1 \\
\hline $1-5$ & 160 & 41,0 & Orta & 278 & 71,3 \\
\hline $6-10$ & 169 & 43,3 & Büyük & 22 & 5,6 \\
\hline 11 yıl ve üzeri & 57 & 14,6 & & \\
\hline
\end{tabular}

Tablodan görüleceği üzere, katılımcıların çalıştı̆̆ firmaların büyük bir kısmı $(\% 43,3) 6$ ile 10 yıldır imalat sanayiinde faaliyet göstermektedir. Firma büyüklüğüne bakıldığında, firmaların \%71,3'ünün orta büyüklükte işletme olduğu anlaşılmaktadır.

\section{Analiz ve Bulgular}

\section{Ölçeklerin Geçerlilik ve Güvenilirlik Analizleri}

Araştırma analizlerinde, değişkenlerin yapısını belirlemek öncelikli adım olarak benimsenmiştir. Bu kapsamda, ölçeklerin yapısını ve boyutlarını belirlemek için açıklayıc faktör analizi uygulanmıştır. Daha detaylı ifade etmek gerekirse, faktör analizinde boyutların belirlenmesinde özdeğer, çizgi grafik ve açıklanan varyans oranları incelenmiştir. Analiz işlemleri için temel bileşenler ve varimax yöntemleri uygulanmıştır.

Dönüşümcü liderlik için faktör analizi şartlarına uymayan "İşleri gerçekleştirme biçimimi sürekli gözden geçirmem için beni uyarır." ifadesi analizden çıkarılmıştır. Tablo 3, dönüşümcü liderlik ölçeğinin faktör analizi sonuçlarını göstermektedir. Tablodaki ifadeler ait oldukları boyutun içinde faktör ağırlıklarına göre sıralanmıştır. 
Tablo 3. Açıklayıcı Faktör Analizi - Dönüşümcü Liderlik

\begin{tabular}{|c|c|c|c|}
\hline Faktörün Adı & İfadeler & Faktör Ağırlıkları & $\%$ \\
\hline \multirow{8}{*}{$\begin{array}{l}\text { Vizyon, } \\
\text { İham Sağlama, } \\
\text { Uygun } \\
\text { Rol } \\
\text { Model Olma }\end{array}$} & $\begin{array}{l}\text { Çalışanlara sözlerinden çok davranışlarıyla örnek } \\
\text { olur. }\end{array}$ & ,791 & \multirow{8}{*}{22,050} \\
\hline & $\begin{array}{l}\text { İşyerinin gelecekteki durumunu çalışanlara anlat- } \\
\text { maya çalışır. }\end{array}$ & ,784 & \\
\hline & $\begin{array}{l}\text { Çalışanların belirlenen amaçlara bağlılık duyma- } \\
\text { larına önem verir. }\end{array}$ & ,772 & \\
\hline & $\begin{array}{l}\text { Benim için izlenecek, örnek alınacak bir yönetici- } \\
\text { dir. }\end{array}$ & 689 & \\
\hline & Bu işyeri için daima yeni fırsatlar arar. & 654 & \\
\hline & $\begin{array}{l}\text { Çalışanlara, geleceğe ilişkin planlarıyla ilham ver- } \\
\text { meye çalışır. }\end{array}$ & ,622 & \\
\hline & $\begin{array}{l}\text { Bu işyerinin gelecekteki durumuna ilişkin net bir } \\
\text { fikre sahiptir. }\end{array}$ &, 551 & \\
\hline & Başarılara ve amaçlara ulaşmayı sembolleştirir. &, 548 & \\
\hline \multirow{6}{*}{$\begin{array}{l}\text { Yüksek Başarı } \\
\text { Beklentisine } \\
\text { Sahip Olma ve } \\
\text { Entelektüel } \\
\text { Teşvikte } \\
\text { Bulunma }\end{array}$} & $\begin{array}{l}\text { Faaliyetlerimizi değerlendirirken ikinci en iyiyi } \\
\text { başarı olarak görmez. }\end{array}$ &, 817 & \multirow{6}{*}{18,043} \\
\hline & $\begin{array}{l}\text { Bizden her zaman en iyisini, daha iyisini yapma- } \\
\text { mızı bekler. }\end{array}$ & ,782 & \\
\hline & $\begin{array}{l}\text { Bizden çok şey beklediğini, bize açıkça söyler ve } \\
\text { belli eder. }\end{array}$ & ,666 & \\
\hline & Benim duygularımı dikkate alarak davranır. & 621 & \\
\hline & Benim kişisel duygularıma saygı gösterir. & 600 & \\
\hline & $\begin{array}{l}\text { Benim kişisel ihtiyaçlarımı göz önüne alarak dav- } \\
\text { ranır. }\end{array}$ &, 547 & \\
\hline \multirow{5}{*}{$\begin{array}{l}\text { Grup } \\
\text { Amaçlarının } \\
\text { Kabulünü } \\
\text { Sağlama }\end{array}$} & $\begin{array}{l}\text { Çalışanları (grubu) aynı amaca dönük olarak çalış- } \\
\text { maya sevk eder. }\end{array}$ & 800 & \multirow{5}{*}{16,394} \\
\hline & $\begin{array}{l}\text { İşyeri içi takım çalışmalarında iş birliğini sürekli } \\
\text { hale getirir. }\end{array}$ & ,793 & \\
\hline & $\begin{array}{l}\text { Çalışanlarda takım düşüncesinin ve ruhunun } \\
\text { oluşmasını sağlamaya çalışır. }\end{array}$ & 670 & \\
\hline & $\begin{array}{l}\text { Çalışanların, "takım oyuncusu" olmalarını sağla- } \\
\text { maya çalışır. }\end{array}$ & ,592 & \\
\hline & $\begin{array}{l}\text { Bu işyerinin amaçlarının oluşturulmasında çalı- } \\
\text { şanların katılımını sağlar. }\end{array}$ & ,582 & \\
\hline \multirow{7}{*}{$\begin{array}{l}\text { Bireysel } \\
\text { Gösterme }\end{array}$} & $\begin{array}{l}\text { İşime ve kariyerime ilişkin beklentilerimi yükselt- } \\
\text { memi sağlamaya çalışır. }\end{array}$ & 824 & \multirow{3}{*}{12,014} \\
\hline & $\begin{array}{l}\text { Beni, rutin sorunları yeni bir bakış açısı ile çöz- } \\
\text { meye teşvik eder. }\end{array}$ & ,794 & \\
\hline & Beni düşünmeye sevk eden sorular sorar. & 611 & \\
\hline & \multirow{2}{*}{\multicolumn{2}{|c|}{$\begin{array}{r}\text { Toplam } \\
\text { Kaiser-Meyer-Olkin Ölçek Geçerliliği }\end{array}$}} & 68,501 \\
\hline & & & 0,948 \\
\hline & \multirow{2}{*}{ Bartlett's Küresellik Testi } & Ki Kare & 6108,864 \\
\hline & & p değeri & 0,000 \\
\hline
\end{tabular}

Tablo 3'deki sonuçlara göre, elde edilen KMO değeri 0,948; Bartlett küresellik testi 0,50 üzerinde ve 0,05 düzeyinde istatistiksel olarak anlamlıdır. 
Analiz sonucuna göre ölçekte özdeğeri 1'in üzerinde olan dört boyut belirlenmiştir. Bu boyutlar; "Vizyon, İlham Sağlama, Uygun Rol Model Olma”, "Yüksek Başarı Beklentisine Sahip Olma ve Entelektüel Teşvikte Bulunma", “Grup Amaçlarının Kabulünü Sağlama” ve "Bireysel İlgi Gösterme” olarak anlamlandırılmıştır. Toplam açıklanan varyans \%68,5 olarak tespit edilmiştir.

Dönüşümcü liderlikte olduğu gibi, değişim mühendisliği ölçeğinin yapısı ve boyutları da faktör analizi ile test edilmiştir. Tablo 4'de analiz sonuçları gösterilmektedir. Faktör analizi şartlarına uymayan üç anket maddesi analizden çıkarılmıştır.

\section{Tablo 4. Açıklayıcı Faktör Analizi - Değişim Mühendisliği}

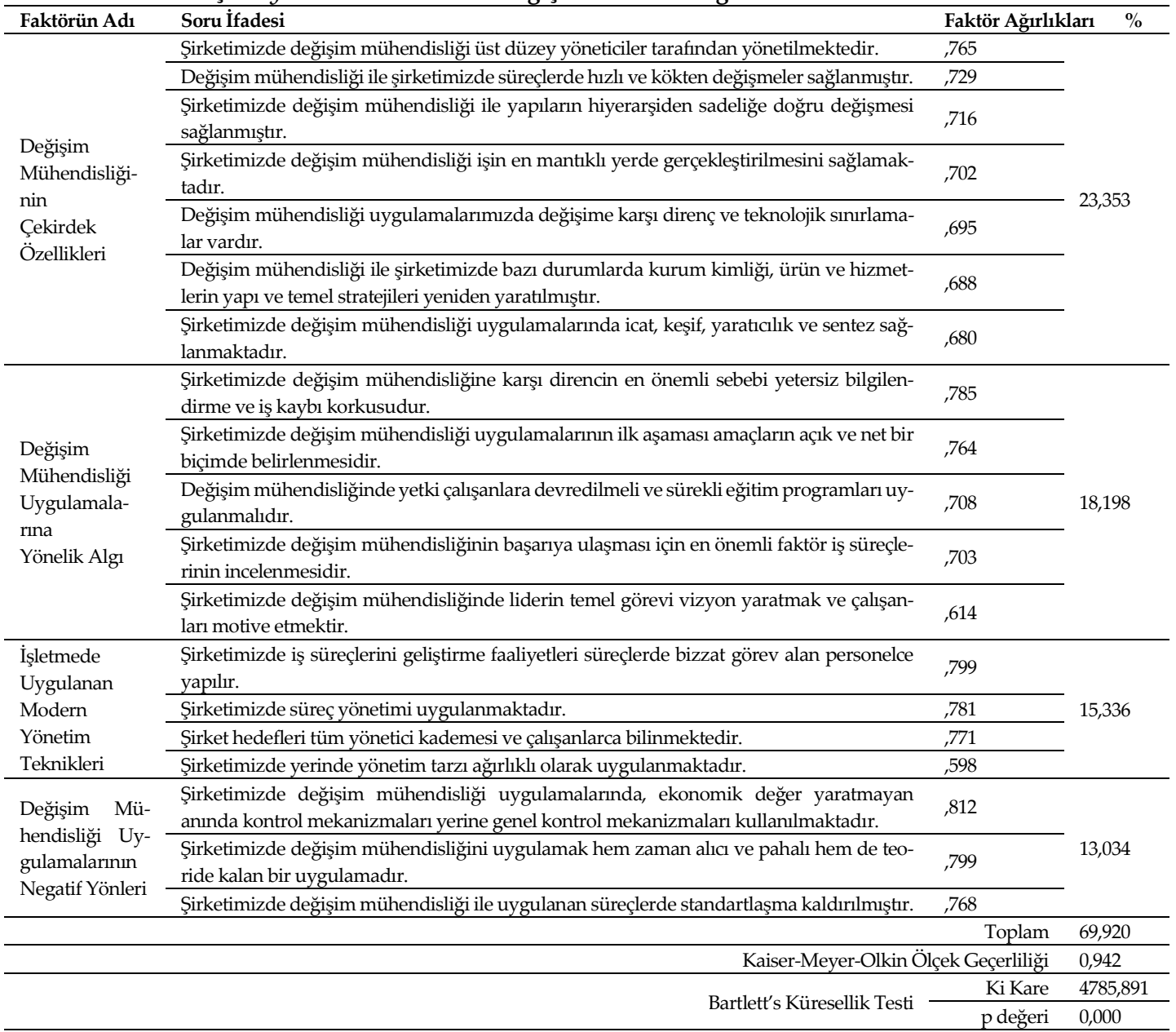


Tablo 4'deki sonuçlara göre, elde edilen KMO değeri 0,942; Bartlett küresellik testi 0,50 üzerinde ve 0,05 düzeyinde istatistiki olarak anlamlıdır. Bulgulara göre ölçekte, özdeğeri 1'in üzerinde olan dört boyut tespit edilmiştir. Bu boyutlar; “Değişim Mühendisliğinin Çekirdek Özellikleri”, “Değişim Mühendisliği Uygulamalarına Yönelik Algı", "Işletmede Uygulanan Modern Yönetim Teknikleri" ve "Değişim Mühendisliği Uygulamalarının Negatif Yönleri" olarak anlamlandırılmıştır. Toplam açıklanan varyans \%69,9 olarak tespit edilmiştir.

Son olarak, örgüt performansı ölçeğinin yapısı ve boyutları faktör analizi ile test edilmiş olup, analiz sonuçları Tablo 5'de gösterilmektedir. Faktör analizi şartlarına uymayan üç anket maddesi analizden çıarılmıştır.

\section{Tablo 5. Açıklayıcı Faktör Analizi - Örgüt Performansı}

\begin{tabular}{|c|c|c|c|}
\hline Faktörün Adı & Soru İfadesi & Faktör Ağırlıkları & $\%$ \\
\hline \multirow{7}{*}{$\begin{array}{l}\text { Finansal } \\
\text { Performans }\end{array}$} & Büyüme oranımız rakiplerimden yüksektir. & ,817 & \multirow{7}{*}{37,514} \\
\hline & Kârlılı̆ıııı (yüzde olarak) rakiplerimizden yüksektir. & 800 & \\
\hline & $\begin{array}{l}\text { Ciro kârlılığımız (Kar/Toplam Satışlar) rakiplerimizden } \\
\text { yüksektir. }\end{array}$ & ,762 & \\
\hline & Yatırımlarınızın getirisi rakiplerimizden yüksektir. & ,751 & \\
\hline & Piyasa payımız rakiplerimizden yüksektir. & ,741 & \\
\hline & Faaliyet gelirlerimiz rakiplerimizden yüksektir. & ,688 & \\
\hline & $\begin{array}{l}\text { Şirketimizin piyasa değeri rakiplerimizinkinden yük- } \\
\text { sektir. }\end{array}$ & 658 & \\
\hline \multirow{9}{*}{$\begin{array}{l}\text { Finansal } \\
\text { Olmayan } \\
\text { Performans }\end{array}$} & $\begin{array}{l}\text { Çalsşan başına ortalama üretkenliğimiz rakiplerimizden } \\
\text { yüksektir. }\end{array}$ & 868 & \multirow{5}{*}{30,810} \\
\hline & $\begin{array}{l}\text { Çalşsanlarımızın yeni beceri öğrenme sayısı rakipleri- } \\
\text { mizden yüksektir. }\end{array}$ & 837 & \\
\hline & $\begin{array}{l}\text { Müşteri şikâyetlerine cevap verme süremiz rakipleri- } \\
\text { mizden daha hızlıdır. }\end{array}$ &, 811 & \\
\hline & $\begin{array}{l}\text { Ürünü/hizmeti üretip piyasaya verme süremiz rakiple- } \\
\text { rimizden daha hızlıdır. }\end{array}$ & ,682 & \\
\hline & Müşteri memnuniyetimiz rakiplerimizden yüksektir. & ,632 & \\
\hline & & Toplam & 68,323 \\
\hline & \multicolumn{2}{|c|}{ Kaiser-Meyer-Olkin Ölçek Geçerliliği } & 0,936 \\
\hline & \multirow{2}{*}{ Bartlett's Küresellik Testi } & Ki Kare & 3102,899 \\
\hline & & p değeri & 0,000 \\
\hline
\end{tabular}

Tablo 5'deki sonuçlara göre, elde edilen KMO değeri 0,936; Bartlett küresellik testi 0,50 üzerinde ve 0,05 düzeyinde istatistiki olarak anlamlıdır. Bulgulara göre ölçekte, özdeğeri 1'in üzerinde olan iki boyut tespit edilmiştir. Bu boyutlar; "Finansal Performans" ve "Finansal Olmayan Performans" olarak anlamlandırılmıştır. Toplam açıklanan varyans \%68,3 olarak tespit edilmiştir. 
Faktör analizi sonuçlarından sonra, ifadelerin içsel tutarlılı̆̆ güvenilirlik analizi ile ölçülmüş, bu amaçla içsel tutarlılığın test edilmesinde Cronbach's Alpha katsayısı kullanılmıştır. Tablo 6, ölçeğe ait güvenilirlik analizi sonuçlarını göstermektedir.

Tablo 6. Güvenilirlik Analizi Sonuçlan

\begin{tabular}{lll}
\hline Ölçek & Soru Sayısı & Güvenilirlik Katsayısı \\
\hline Vizyon, İlham Sağlama, Uygun Rol Model Olma & 8 & 0,929 \\
\hline $\begin{array}{l}\text { Yüksek Başarı Beklentisine Sahip Olma ve Entelektüel } \\
\text { Teşvikte Bulunma }\end{array}$ & 6 & 0,895 \\
\hline Grup Amaçlarının Kabulünü Sağlama & 5 & 0,873 \\
\hline Bireysel İlgi Gösterme & 3 & 0,805 \\
\hline Dönüşümcü Liderlik & 22 & 0,955 \\
\hline Değişim Mühendisliğinin Çekirdek Özellikleri & 7 & 0,915 \\
\hline Değişim Mühendisliği Uygulamalarına Yönelik Algı & 5 & 0,878 \\
\hline İşletmede Uygulanan Modern Yönetim Teknikleri & 4 & 0,858 \\
\hline $\begin{array}{l}\text { Değişim Mühendisliği Uygulamalarının Negatif } \\
\text { Yönleri }\end{array}$ & 3 & 0,865 \\
\hline Değişim Mühendisliği & 19 & 0,944 \\
\hline Finansal Performans & 7 & 0,913 \\
\hline Finansal Olmayan Performans & 5 & 0,895 \\
\hline Örgüt Performans & 12 & 0,934 \\
\hline
\end{tabular}

Tablo 6'daki katsayılar incelendiğinde Cronbach's Alpha katsayılarının 0,805 ile 0,955 arasında olduğu görülmektedir. Elde edilen sonuçlar, alan yazında kabul edilen 0,60 alt sınırını sağlamaktadır (Kalaycı, 2009, s. 405). Bu sonuçlara göre, araştırmada kullanılan ölçeklerin ve boyutların yüksek derece içsel tutarlılığa sahip olduğu belirlenmiştir.

\section{Korelasyon Analizi}

Araştırma hipotezleri doğrultusunda bağımlı ve bağımsız değişkenler arasındaki ilişkiler Pearson korelasyon katsayısı ile ölçülmüş olup, elde edilen bulgular Tablo 7'de gösterilmektedir. Sonuçlar incelendiğinde tüm değişkenlerin \%99 güvenilirlik düzeyinde pozitif yönlü ilişkisi olduğu anlaşılmaktadır. Yani, bir değişkendeki olumlu artış diğer değişkenlerde de olumlu bir artışa sebep olmaktadır. Buna göre, işletmedeki dönüşümcü liderlik uygulamalarındaki olumlu bir yaklaşım performansa ve değişim mühendisliği uygulamalarına da pozitif şekilde yansımaktadır. 
Tablo 7. Korelasyon Analizi Sonuçlarn

\begin{tabular}{|c|c|c|c|c|c|c|c|c|c|c|c|c|c|}
\hline $\begin{array}{l}\text { Değiş- } \\
\text { kenler }\end{array}$ & 1. & 2. & 3. & 4. & 5. & 6. & 7. & 8. & 9. & 10. & 11. & 12. & 13 \\
\hline $\begin{array}{l}1 . \\
\text { DMF1 }\end{array}$ & 1 & & & & & & & & & & & & \\
\hline $\begin{array}{l}2 . \\
\text { DMF2 }\end{array}$ & $\begin{array}{l}\text {,722 } \\
* *\end{array}$ & 1 & & & & & & & & & & & \\
\hline $\begin{array}{l}3 . \\
\text { DMF3 }\end{array}$ & $\begin{array}{l}\text {,627 } \\
* *\end{array}$ & $\begin{array}{l}, 602 \\
* *\end{array}$ & 1 & & & & & & & & & & \\
\hline $\begin{array}{l}4 . \\
\text { DMF4 }\end{array}$ & $\begin{array}{l}, 587 \\
* *\end{array}$ & $\begin{array}{l}, 538 \\
* *\end{array}$ & $\begin{array}{l}, 592 \\
* *\end{array}$ & 1 & & & & & & & & & \\
\hline 5. DM & $\begin{array}{l}, 708 \\
* * \\
\end{array}$ & $\begin{array}{l}762 \\
* * \\
\end{array}$ & $\begin{array}{l}, 813 \\
* * \\
\end{array}$ & $\begin{array}{l}\text {,771 } \\
* * \\
\end{array}$ & 1 & & & & & & & & \\
\hline $\begin{array}{l}6 . \\
\text { DLF1 }\end{array}$ & $\begin{array}{l}698 \\
* * \\
\end{array}$ & $\begin{array}{l}, 759 \\
* * \\
\end{array}$ & $\begin{array}{l}, 671 \\
* * \\
\end{array}$ & $\begin{array}{l}603 \\
* * \\
\end{array}$ & $\begin{array}{l}, 801 \\
* * \\
\end{array}$ & 1 & & & & & & & \\
\hline $\begin{array}{l}7 . \\
\text { DLF2 } \\
\end{array}$ & $\begin{array}{l}, 843 \\
* * * \\
\end{array}$ & $\begin{array}{l}\text {,763 } \\
* * \\
\end{array}$ & $\begin{array}{l}660 \\
* * \\
\end{array}$ & $\begin{array}{l}603 \\
* * \\
\end{array}$ & $\begin{array}{l}769 \\
* * \\
\end{array}$ & $\begin{array}{l}729 \\
* * \\
\end{array}$ & 1 & & & & & & \\
\hline $\begin{array}{l}8 . \\
\text { DLF3 }\end{array}$ & $\begin{array}{l}702 \\
* * \\
\end{array}$ & $\begin{array}{l}\text {,799 } \\
* * \\
\end{array}$ & $\begin{array}{l}, 576 \\
* * \\
\end{array}$ & $\begin{array}{l}, 530 \\
* * \\
\end{array}$ & $\begin{array}{l}805 \\
* * \\
\end{array}$ & $\begin{array}{l}710 \\
* * \\
\end{array}$ & $\begin{array}{l}, 726 \\
* * \\
\end{array}$ & 1 & & & & & \\
\hline $\begin{array}{l}9 . \\
\text { DLF4 }\end{array}$ & $\begin{array}{l}, 597 \\
* * \\
\end{array}$ & $\begin{array}{l}, 561 \\
* * \\
\end{array}$ & $\begin{array}{l}, 833 \\
* * \\
\end{array}$ & $\begin{array}{l}601 \\
* * \\
\end{array}$ & $\begin{array}{l}750 \\
* * \\
\end{array}$ & $\begin{array}{l}644 \\
* * \\
\end{array}$ & $\begin{array}{l}, 610 \\
* * \\
\end{array}$ & $\begin{array}{l}, 545 \\
* * \\
\end{array}$ & 1 & & & & \\
\hline 10. DL & $\begin{array}{l}, 824 \\
* * \\
\end{array}$ & $\begin{array}{l}768 \\
* * \\
\end{array}$ & $\begin{array}{l}, 764 \\
* * \\
\end{array}$ & $\begin{array}{l}669 \\
* * \\
\end{array}$ & $\begin{array}{l}\text {,733 } \\
* * \\
\end{array}$ & $\begin{array}{l}725 \\
* * \\
\end{array}$ & $\begin{array}{l}, 803 \\
* * \\
\end{array}$ & $\begin{array}{l}809 \\
* * \\
\end{array}$ & $\begin{array}{l}758 \\
* * \\
\end{array}$ & 1 & & & \\
\hline $\begin{array}{l}\text { 11.OP } \\
\text { F1 }\end{array}$ & $\begin{array}{l}, 749 \\
* *\end{array}$ & $\begin{array}{l}736 \\
* *\end{array}$ & $\begin{array}{l}\text {,648 } \\
* *\end{array}$ & $\begin{array}{l}, 593 \\
* *\end{array}$ & $\begin{array}{l}798 \\
* *\end{array}$ & $\begin{array}{l}\text {,733 } \\
* *\end{array}$ & $\begin{array}{l}, 807 \\
* *\end{array}$ & $\begin{array}{l}708 \\
* * \\
* *\end{array}$ & $\begin{array}{l}605 \\
* *\end{array}$ & $\begin{array}{l}755 \\
* *\end{array}$ & 1 & & \\
\hline $\begin{array}{l}12 . \\
\text { OPF2 }\end{array}$ & $\begin{array}{l}\text { 673 } \\
* *\end{array}$ & $\begin{array}{l}728 \\
* *\end{array}$ & $\begin{array}{l}640 \\
* *\end{array}$ & $\begin{array}{l}, 594 \\
* *\end{array}$ & $\begin{array}{l}782 \\
* *\end{array}$ & $\begin{array}{l}770 \\
* *\end{array}$ & $\begin{array}{l}\text { 695 } \\
* *\end{array}$ & $\begin{array}{l}678 \\
* *\end{array}$ & $\begin{array}{l}623 \\
* *\end{array}$ & $\begin{array}{l}791 \\
* *\end{array}$ & $\begin{array}{l}\text {,709* } \\
*\end{array}$ & 1 & \\
\hline 13. OP & $\begin{array}{l}\text {,795 } \\
* *\end{array}$ & $\begin{array}{l}791 \\
* *\end{array}$ & $\begin{array}{l}696 \\
* *\end{array}$ & $\begin{array}{l}\text { 641 } \\
* *\end{array}$ & $\begin{array}{l}\text {,715 } \\
* *\end{array}$ & $\begin{array}{l}704 \\
* *\end{array}$ & $\begin{array}{l}808 \\
* *\end{array}$ & $\begin{array}{l}\text {,751 } \\
* *\end{array}$ & $\begin{array}{l}\text { 662 } \\
* *\end{array}$ & $\begin{array}{l}, 741 \\
* *\end{array}$ & $\begin{array}{l}\text {,7042 } \\
* *\end{array}$ & $\begin{array}{l}704 \\
* *\end{array}$ & 1 \\
\hline
\end{tabular}

** Pearson Korelasyonu $\mathrm{p}<0,01$ düzeyinde anlamlıdır.

NOT: DMF1 (Değişim Mühendisliğinin Çekirdek Özellikleri), DMF2 (Değişim Mühendisliği Uygulamalarına Yönelik Alg1), DMF3 (İşletmede Uygulanan Modern Yönetim Teknikleri), DMF4 (Değişim Mühendisliği Uygulamalarının Negatif Yönleri), DM (Değişim Mühendisliği), DLF1 (Vizyon, İlham Sağlama, Uygun Rol Model Olma), DLF2 (Yüksek Başarı Beklentisine Sahip Olma ve Entelektüel Teşvikte Bulunma), DLF3 (Grup Amaçlarının Kabulünü Sağlama), DLF4 (Bireysel İlgi Gösterme), DL (Dönüşümcü Liderlik), OPF1 (Finansal Performans), OPF2 (Finansal Olmayan Performans), ÖP (Örgütsel Performans)

\section{Hiyerarşik Regresyon Analizi}

Mevcut araştırmada, hipotezlerin test edilmesinde hiyerarşik regresyon analizi kullanılmıştır. Bu sayede, araştırmaya konu olan ana değişkenlerin (dönüşümcü liderlik, değişim mühendisliği ve örgüt performansı) ve bu ana değişkenler arasındaki nedensel ilişkilerin açıklanabileceği varsayılmıştır. Buna 
ek olarak, dönüşümcü liderliğin örgüt performansına etkisinde değişim mühendisliğinin aracı rolü için de, Baron ve Kenny'in (1986) önerdiği aşamalar uygulanmıştır.

Tablo 8. Hiyerarşik Regresyon Analizi

\begin{tabular}{|c|c|c|c|c|c|c|c|}
\hline & $\begin{array}{l}\text { Standartlaştı- } \\
\text { rilmamış } \beta\end{array}$ & $\begin{array}{l}\text { Standartlaştırıl- } \\
\text { mamış Std. Hata }\end{array}$ & Sdt. $\beta$ & $\mathrm{p}$ & F & $\mathbf{R}$ & $\mathbf{R}^{2}$ \\
\hline $\begin{array}{l}\text { Model } 1 \\
\text { Sabit }\end{array}$ & 147 & ,064 & & ,022 & \multirow{5}{*}{$995,336^{*}$} & \multirow{5}{*}{,955 } & \multirow{5}{*}{,912 } \\
\hline DLF2 & ,011 & , 034 & ,012 & ,734 & & & \\
\hline DLF3 & ,282 & ,031 & ,291 & ,000 & & & \\
\hline DLF4 & ,165 & 022 & ,190 & ,000 & & & \\
\hline $\begin{array}{l}\text { Dönüşümcü } \\
\text { Liderlik }\end{array}$ & ,399 & ,064 & ,324 & ,000 & & & \\
\hline $\begin{array}{l}\text { Model } 2 \\
\text { Sabit } \\
\end{array}$ & ,024 & ,045 & &, 590 & \multirow{10}{*}{$1106,886^{*}$} & \multirow{10}{*}{979} & \multirow{10}{*}{ 959 } \\
\hline DLF2 & ,210 & , 026 & ,224 & ,190 & & & \\
\hline DLF3 & ,112 & , 026 & ,123 & ,000 & & & \\
\hline DLF4 & , 122 & ,019 & ,109 & ,000 & & & \\
\hline $\begin{array}{l}\text { Dönüşümcü } \\
\text { Liderlik }\end{array}$ & ,300 & 047, & 230 & ,000 & & & \\
\hline DMF1 & ,409 & ,020 & ,422 & ,000 & & & \\
\hline DMF2 & , 105 & , 025 & , 105 & ,848 & & & \\
\hline DMF3 & ,100 & ,019 & ,101 & 979 & & & \\
\hline DMF4 & ,104 & ,011 & ,106 & 687 & & & \\
\hline $\begin{array}{l}\text { Değişim } \\
\text { Mühendisliği }\end{array}$ & 103 & ,012 & 109 & ,000 & & & \\
\hline
\end{tabular}

Tablo 8' de belirtilen ilk model; sadece dönüşümcü liderlik ve boyutları ile örgüt performansı arasındaki ilişkiyi; ikinci model ise dönüşümcü liderlik ve boyutları bağımsız değişkenlerinin, değişim mühendisliğinin aracı rolünde örgüt performansı üzerindeki etkisini göstermektedir. İlk model varyansın \%91,2'sini açıklarken; değişim mühendisliği eklendiğinde varyansın \%95,9'unu açıklamaktadır. Yani, ara değişken olarak eklenen değişim mühendisliği varyansın toplam \%4,7'sini daha açıklamaktadır. Ayrıca kurulan bu modelin \%95 güvenilirlik düzeyinde anlamlı olduğu görülmektedir.

Birinci modeldeki analiz sonuçları detaylı incelendiğinde; dönüşümcü liderlikte yer alan "vizyon, ilham sağlama, uygun rol model olma", "grup amaçlarının kabulünü sağlama" ve "bireysel ilgi gösterme" ile örgüt performansı arasında pozitif yönlü ilişki olduğu \%95 güvenilirlik düzeyinde görülmektedir. Buna karşılık, analizlerde "yüksek başarı beklentisine sahip olma" 
ve "entelektüel teşvikte bulunma" ile örgüt performansı arasında ilişki bulunmadığ $\% 95$ güvenilirlik düzeyinde belirlenmiştir $(p>0,05)$.

İkinci modeldeki analiz sonuçları detaylı incelendiğinde; dönüşümcü liderlik bağımsız değişkeninin, değişim mühendisliğinin ara değişkenliğinde, örgüt performansı üzerinde istatistiki olarak etkisi olduğu ve bu etkinin azaldığı görülmektedir. Buna göre, değişim mühendisliğinin modelde kısmi ara değişken etkisi gösterdiği anlaşılmaktadır $(\beta=0,109 \mathrm{p}=0,000<0,05)$. Ayrıca, "değişim mühendisliğinin çekirdek özellikleri" ara değişkeninin de modelde kısmi etkisi olduğu görülmektedir $(\beta=0,422 p=0,000<0,05)$. Elde edilen tüm bulgular incelendiğinde hipotezlerin durumu Tablo $9^{\prime}$ da sunulmaktadır.

Tablo 9. Hipotez Sonuçlan

\begin{tabular}{lll}
\hline & Hipotez & Durum \\
\hline $\mathbf{H}_{1}$ & Dönüşümcü liderlik değişim mühendisliğini etkilemektedir. & Kabul \\
\hline $\mathbf{H}_{2}$ & Değişim mühendisliği örgüt performansını etkilemektedir. & Kabul \\
\hline $\mathbf{H}_{3}$ & Dönüşümcü liderlik örgüt performansını direkt olarak etkilemektedir. & Kabul \\
\hline $\mathbf{H}_{4}$ & $\begin{array}{l}\text { Değişim mühendisliği, dönüşümcü liderlik ve örgüt performansı arasında } \\
\text { ara değişkendir. }\end{array}$ & Kabul \\
\hline
\end{tabular}

Tablo 9'dan da görüleceği üzere, araştırmada yer alan hipotezlerin hepsi kabul edilmektedir. Böylece, dönüşümcü liderliğin örgüt performansına hem direkt, hem de dolaylı etki ettiği ve bu dolaylı etkide değişim mühendisliğinin örgüt performansına direkt etki etmesinin yanı sıra, mevcut ilişkide ara değişken etkisinin de bulunduğu saptanmıştır.

\section{Sonuç ve Öneriler}

Son yıllarda yaşanan gelişmeler doğrultusunda artan rekabet, ancak düşük verimliliğe karşın, üretim alanındaki örgütler tedarik zinciri içerisinde bulunan birçok paydaş ile (tedarikçi, çalışan, müşteri, lojistik servis sağlayıcısı gibi) kârlılık ve verimliliklerini arttıracak stratejileri keşfetmeye mecbur kalmaktadırlar (Burawat, 2017). Bu stratejiler doğrultusunda kendi iç dinamiklerinde de değişime giderek, performans çıktılarından maksimum fayda elde etme arayışına girmektedirler. Değişim için gerekli olan koşullar içerisinde dönüşümcü liderlik ve değişim mühendisliği anlayışının göz ardı edilemeyecek rolü bulunmaktadır ve tüm bu unsurlar, örgütlerin belirlemiş olduğu per- 
formans göstergeleri üzerinden örgüt performansını direkt veya dolaylı olarak etkileyebilmektedir. Dolayısıyla, değişen dünya koşullarında ve işletme çevrelerindeki zorlu rekabet içerisinde, örgütler bu kavramlara daha çok önem vererek, daha rekabetçi hale gelmenin arayışına girmektedirler. Buradan hareketle, mevcut araştırma, bahsi geçen üç kavrama ilişkin belirlemiş olduğu dört hipotez ile bu kavramlar arası etkileşimin düzeyini analiz etmektedir. İstanbul'da imalat sanayiinde çalışan 390 kişiden elde edilen verilerin analizleri neticesinde aşağıdaki bulgulara ulaşılmıştır:

- Dönüşümcü liderlik, değişim mühendisliği ve örgüt performansı arasındaki ilişkiler korelasyon analizine göre pozitif yönlü ve istatistiksel olarak anlamlıdır. Yani bir değişkendeki olumlu bir değişim, diğer değişkenlerde de olumlu bir artışa neden olmaktadır.

- Dönüşümcü liderlik ve örgüt performansı arasındaki etkinin istatistiksel olarak anlamlı olduğu görülmektedir.

- Değişim mühendisliği ara değişken olarak modele dahil edildiğinde, dönüşümcü liderlik ve örgüt performansı arasındaki ilişkinin azaldığı fakat, istatistiksel olarak anlamlılığının devam ettiği görülmektedir. Bu durum, değişim mühendisliğinin, kısmi olarak modelde aracllı etkisine sahip olduğunu göstermektedir.

Sonuç olarak, imalat sanayii örnekleminde yapılan anket çalışması, araştırmada bahsi geçen kavramlar arası ilişkilere dair genelleştirilebilir ifadelerin oluşmasına ışık tutmaktadır. Daha detaylı bir ifadeyle, elde edilen bulgular, bir yandan dönüşümcü liderlik özelliği gösteren karar vericilerin örgüt performansını direkt olarak pozitif şekilde etkileyebileceğini ortaya koyarken, diğer yandan da dönüşümcü liderlik özelliğine sahip olmanın değişim mühendisliğine olan olumlu etkisi ile beraber örgüt performansını dolaylı olarak da pozitif şekilde etkileyebileceğini ortaya koymaktadır. Böylelikle, mevcut araştırmada yer verilen değişkenlerin ilişkileri ile ilgili olarak ifade edilen tüm hipotezler de bulgular neticesinde istatiksel olarak kabul edilmiştir.

Araştırma akademik açıdan literatüre katkı yapması anlamında oldukça büyük potansiyele sahiptir. Nitekim, Türkçe ve İngilizce olarak literatür araştırmasında kullanılan anahtar kelimeler sonrasında, imalat sanayii için dönüşümcü liderlik ve değişim mühendisliğinin beraber incelendiği bir çalışmaya rastlanılmamıştır. Bunun yanı sıra, dönüşümcü liderlik ve performans üzerine olan oldukça sınırlı sayıdaki literatürün ise, örgüt performansından zi- 
yade genellikle personel verimine ve iş performansına dayandığı gözlemlenmiştir. Böylece, imalat sanayiii bağlamında araştırmaya konu olan üç kavramla ilişkilendirilen bir çalışmanın eksikliği, mevcut araştırmanın özgünlügünü ortaya koymaktadır.

Mevcut araştırma pratik açıdan da katkı sunmaktadır. Bu hususta, örgüt içerisinde karar verici pozisyonda yer alan üst yönetim kademelerinde çal1şanlar, dönüşümcü liderliğin ve değişim mühendisliğinin örgüt performanslarına olan etkisini gözlemleyebilecek, böylece elde edilen bulgular çerçevesinde organizasyon yapılarını şekillendirerek daha rekabetçi hale gelebileceklerdir.

Araştırmanın mevcut kısıtları ise şu şekildedir. Temelde iki veritabanının incelenmesi ve araştırmada belirlenen anahtar kelime çiftlerinin bu veritabanlarında sadece özet, başlık ve anahtar kelimeler kapsamındaki makalelerde aratılması, araştırmayı oldukça sınırlı sayıda bir literatürle karşı karşıya bırakmıştır. Bunun yanı sıra, araştırmanın gerek yalnızca imalat sanayii için yapılması, gerekse de Türkiye bağlamı ile sınırlı kalması araştırmada bir diğer kısıt olmuştur. Dolayısıyla, ileriki çalışmalarda farklı anahtar kelimeler eklenerek ve/veya başka veritabanları ile çeşitlendirilerek daha kapsamlı bir çalışma farklı ülke veya sektör bağlamlarında yapılabilir. Böylece, mevcut araştırmadan elde edilen bulgular ile gelecek çalışmalardaki bulgular karşılaştırılarak hem akademik yazın hem de pratik katkılar daha çok zenginleştirilebilir. 
EXTENDED ABSTRACT

\title{
Examining the Relationship between Transformational Leadership and Performance in Organisations with the Mediating Role of Reengineering: The Case of a Manufacturing Industry
}

\author{
Berk Küçükaltan- Gözde Mert \\ Trakya University, Nişantaşı University
}

\begin{abstract}
Although organisations are defined differently both in academia and in practice, they can be gathered under two main headings with regard to the purposes of conducting their activities. The first of these is for-profit type of organisations that strive to increase their competitiveness and market shares by making profit whereas the other is a not-for-profit type of organisations that focus mainly on making social benefits rather than profits by undertaking a certain mission (Çetin, 2012; Küçükaltan, 2018). In this research, given the existing literature and the research problematic, the for-profit type of organisations is investigated, so that the concepts evaluated between the inputs, processes, and outputs of the organisations are discussed within this scope. Therefore, the concept of organisation defined in this research addresses profit-oriented organisations.

In today's industrial age, organisations need strategic factors, such as organisational culture, information technologies, human capital, and leadership in order to achieve a competitive advantage and thereby aims to combine both structural capital and human capital (Birasnav et al., 2010). By doing so, organisations also make regular updates and developments on several matters, such as talent management and performance processes, which are critical for their positions in industry and business (Parnaby and Towill, 2009). Within the scope of these developments, leadership types, which have strategic importance in the functioning of organisations, received particular attention in the literature. More specifically, considering the last
\end{abstract}


twenty-year period, it can be seen that the impact of transformational leadership on employee behaviour has been extensively studied and, in these research, it is found that the transformational leadership is positively related to some outcome-oriented criteria, such as organisational commitment (Miao et al., 2012).

Although there are such positive developments and experiences regarding organisational processes and strategic factors, it is also observed that there are some gaps in the existing literature in relation to these concepts. For example, despite transformational leadership is widely discussed as an important strategic factor for organisations, research on transformational leadership are generally remained limited to the western organisations, as Miao et al. (2012) underlined. In addition, there are some uncertainties in terms of its conceptual scope, since there is no widely accepted definition for the transformational leadership notion. Similarly, concerning the organisational performance concept, it is difficult to measure the organisational performance, in addition to the difficulty of defining it (Hussein et al., 2014). In this regard, since it is evident that using only financial data, which provide a short- or a medium-term perspective, will not be sufficient for measuring organisational performance, incorporating non-financial criteria is also considered in organisational performance measurement. Accordingly, as summarised by Wan Zakaria and Ilias (2016), several criteria, such as operational performance, improvement in profitability, improvement in organisational and business processes, and achieving predefined goals can be used as example measures for organisational performance. However, it is also vital that in order to experience certain improvement and innovation in organisational performance, some changes must occur in processes and systemic structures and, thus, particular importance to the reengineering concept, pioneered by the manufacturing industry, needs to be given (Chan and Jiang, 2001). Under these circumstances, it is evident that the reengineering concept and the transformational leaders, who can adopt the reengineering understanding, become critical strategic factors in organisations to affect organisational performance.

Thus, given the mentioned research gaps and motivations, the present research conducted in the manufacturing industry includes a model consisting of transformational leadership, reengineering, and organisational performance and seeks answers to the following questions, by exploring the 
interactions between these three concepts that are of importance in organisations' strategies:

How does transformational leadership affect organisational performance?

Does the mediating role of reengineering have a significant relationship in the effect of transformational leadership on organisational performance?

In order to examine the relationships between dependent and independent variables in the research model, a total of 61 statements prepared in the 5-point Likert scale were directed to the people participated in the research. Prior to the questions with regard to the main concepts, six statements concerning the demographics of the respondents and two statements about the information of their companies were also included in the research design.

During the content formation of the variables, certain scales and studies were followed. For instance, in order to measure transformational leadership, the scale developed by Podsakoff et al. (1990), which adapted to Turkish by İscan (2006), was used and the scale consists of 23 expressions within four sub-dimensions. On the other hand, the scales prepared by Dağc1 (2004), Kocakahyaoğlu (2008), and Dokuzer (2006) were used to measure the reengineering concept. Finally, Akgün et al.'s (2009) study, which contains 11 expressions, were used for the organisational performance scale, which consists of two dimensions: financial and non-financial performance.

The field research was carried out between October 2019 and January 2020 with the employees working in the manufacturing industry in Istanbul. Although a total of 402 employees participated in the research, due to the incomplete answers of some survey forms, only the data obtained from 390 respondents were included in the analysis. Table 1 shows the demographics of the respondents included in the research.

According to the given answers, $65.9 \%$ of the participants are male whereas $34.1 \%$ are female; $56.7 \%$ are between the ages of 31 and $40 ; 45.9 \%$ hold bachelor's degree; $33.8 \%$ have been working in the same institution for 6 to 10 years; $29.2 \%$ have more than 11 years of work experience; and 19.5\% work in the accounting / finance department. Most of the companies where the participants work for (43.3\%) have been operating in the manufacturing industry for 6 to 10 years. In terms of the size, $71.3 \%$ of the firms are medium-sized businesses. 
At the end of the analyses for the relationships between the variables, based on the data obtained from 390 people working in the manufacturing industry, the following findings were reached:

According to correlation analysis, the relationships between transformational leadership, reengineering, and organisational performance are positive and statistically significant. In other words, a positive change in one variable causes a positive increase in other variables.

The effect between transformational leadership and organisational performance is statistically significant at the level of $\beta=0,324$.

When the reengineering is included into the model as a mediating variable, the relationship between transformational leadership and organisational performance decreases $(\beta=0,230)$; however, its statistical significance continues (See Table 8). This shows that the reengineering variable has a partial mediating effect on the model.

The research holds great potential to contribute to the extant literature. In fact, based on the keywords used in the literature searches both in Turkish and in English, no study was found in terms of exploring transformational leadership and reengineering together for the manufacturing industry. In addition, the existing limited number of literature on transformational leadership and performance is largely based on staff efficiency and job performance rather than investigating organisational performance. Thus, the lack of study in relation to examining these three concepts in the manufacturing industry reveals the originality of this research.

On the other hand, the present research also offers practical contributions. In this regard, by utilising the findings of this research, those working in high level positions in organisations- as decision makers- can be able to comprehend the impacts of transformational leadership and reengineering on organisational performance and, thereby, they can make relevant changes (and take some measures, if needed) in their organisations in order to become more competitive.

The limitations of the research are as follows. Using two databases and searching the keyword pairs within abstracts, titles, and keywords of the articles revealed from these databases limited the literature to be explored by this research. In addition to this, focusing solely on the manufacturing industry, especially only in the Turkish context, adds further limitations to the research. Therefore, in future studies, a more comprehensive research 
can be performed by adding different keywords and databases in different country or sector contexts. In this way, the obtained findings from this research can be compared with further study findings and, thereby, both academic and practical contributions can be enriched.

\section{Kaynakça / References}

Afonina, A. (2015). Strategic management tools and techniques and organizational performance: Findings from the Czech Republic. Journal of Competitiveness, 7(3), 19-36

Akgün, A. E., Keskin, H. ve Byrne, J. (2009). Organizational emotional capability, product and process innovation, and firm performance: An empirical analysis. Journal of Engineering and Technology Management, 26(3), 103-130.

Ardichvili, A. ve Gasparishvili, A. (2001). Leadership profiles of managers in post-communist countries: A comparative study. Leadership \& Organization Development Journal, 22(2), 62-69.

Baron, R. M. ve Kenny, D. A. (1986). The moderator-mediator variable distinction in social psychological research: Conceptual, strategic, and statistical considerations. Journal of Personality and Social Psychology, 51(6), 1173-1182

Bass, B. M. (1985). Leadership and performance beyond expectations. New York: Free Press.

Bay, M. ve Akpınar, S. (2017). Liderlik tarzları ve girişimcilik özellikleri üzerine bir uygulama. Journal of International Social Research, 10(52). 964-973

Birasnav, M., Rangnekar, S. ve Dalpati, A. (2010). Transformational leadership, interim leadership, and employee human capital benefits: An empirical study. Procedia-Social and Behavioral Sciences, 5, 1037-1042.

Burawat, P. (2017). The mediate effect of lean manufacturing on the relationship between transaformational leadership and sustainability performance in thai sMEs. International Journal of Applied Engineering Research, 12(21), 11647-11657.

Burawat, P. (2019). the relationships among transformational leadership, sustainable leadership, lean manufacturing and sustainability performance in thai smes manufacturing industry. International Journal of Quality \& Reliability Management, 36(6), 1014-1036.

Çetin, C. (2012). Temel işletmeciliğe giriş. İstanbul: Beta Yayınları.

Chan, F. T. ve Jiang, B. (2001). The applications of flexible manufacturing technologies in business process reengineering. International Journal of Flexible Manufacturing Systems, 13(2), 131-144. 
Dağcl, A. (2004). Değişim mühendisliği ve banka yöneticilerinin değişim mühendisliği'ne bakış açıları üzerine bir araştırma, Niğde Üniversitesi Sosyal Bilimler Enstitüsü, Yüksek Lisans Tezi, Niğde.

Dokuzer, B. (2006). Modern bir yönetim tekniği olarak benchmarking'in işletmeler tarafindan bilinirliği ve uygulanabilirliğinin saptanmasina yönelik bir araştırma:Niğde örneği, Niğde Üniversitesi Sosyal Bilimler Enstitüsü, Yüksek Lisans Tezi, Niğde.

Eltantawy, R., Paulraj, A., Giunipero, L., Naslund, D. ve Thute, A. A. (2015). Towards supply chain coordination and productivity in a three echelon supply chain: Action research study. International Journal of Operations $\mathcal{E}$ Production Management, 35(6), 895-924.

Eşiyok, A. (2013). Türkiye imalat sanayinin teknolojik yapısı: Sürdürülebilir mi?. Iktisat ve Toplum, 31-32.

Feibert, D. C., Andersen, B. ve Jacobsen, P. (2019). Benchmarking healthcare logistics processes-a comparative case study of danish and US Hospitals. Total Quality Management \& Business Excellence, 30(1-2), 108-134.

Fleming, M. ve Meakin, S. (2004). Cultural maturity model: Health and safety improvement through involvement. In SPE International Conference on Health, Safety, and Environment in Oil and Gas Exploration and Production. (January). Society of Petroleum Engineers.

Gangula, A. (2016). Employability and talent management for the success of organisation-hrd practices and challenges. R.K Miryala ve J. Gade (Eds.), Responsible Tourism \& Human Accountability For Sustainable Business içinde (s. 131-133). Hyderabad: Zenon Academic Publishing.

Hussein, N., Mohamad, A., Noordin, F. ve Ishak, N. A. (2014). Learning organization and its effect on organizational performance and organizational Innovativeness: A proposed framework for Malaysian Public Institutions of Higher Education. Procedia-Social and Behavioral Sciences, 130, 299-304.

İşcan, Ö. F. (2006). Dönüştürücü/etkileşimci liderlik algısı ve örgütsel özdeşleşme ılişkisinde bireysel farklılıkların rolü. Akdeniz İ̈BF Dergisi, 11(6), 160-177.

Kalaycı, Ş. (2009). SPSS uygulamalı çok değişkenli istatistik teknikleri, Asil Yayın, 4. Baski.

Kocakahyaoğlu, K. (2008). Değişim mühendisliği uygulamalarında kıyaslama (benchmarking) ve inşaat sektöründeki yöneticilerin yaklaşımları, Gazi Üniversitesi Sosyal Bilimler Enstitüsü, Yüksek Lisans Tezi, Ankara. 
Küçükaltan, B. (2018). Örgütsel başarı-performans açısından yönetim, Akdemir, A. (Ed.) Örgütlerin Yönetimi: Kavramsal-Kuramsal,Tematik ve Kurumsal Açılardan Yönetim, içinde (s.356-371), İstanbul: Beta Yayınları

Kucukaltan, B., Irani, Z. ve Aktas, E. (2016). A decision support model for identification and prioritization of key performance indicators in the logistics industry. Computers in Human Behavior, 65, 346-358.

Mert, G., Dördüncü, H. ve İncaz, S. (2019). Dönüştürücü liderlik davranışlarının iş tatmini üzerindeki etkisi: Vakıf üniversitesi örneği. Uluslararası Sosyal Araştırmalar Dergisi, 12(65), 1169-1182.

Miao, Q., Newman, A. ve Lamb, P. (2012). Transformational leadership and the work outcomes of Chinese migrant workers: The mediating effects of 1dentification with leader. Leadership, 8(4), 377-395.

Nişancı, Z. N. (2015). Geçmişten günümüze yönetim düşüncesi. Yönetim Bilimleri Dergisi, 13(25), 257-294.

Pado, G. (2017). Müşteri entegrasyonun ışletme performansı üzerine etkileri. Uluslararası Bilimsel Araştırmalar Dergisi (IBAD), 2(2), 296-307.

Parnaby, J. ve Towill, D. R. (2009). Exploiting the concept of a manufacturing system part 11: principles and origins of the managing-by-projects engineering change methodology. Journal of Manufacturing Technology Management, 20(8), 1047-1069.

Podsakoff, P. M., MacKenzie, S. B., Moorman, R. H. ve Fetter, R. (1990). Transformational leader behaviors and their effects on followers' trust in leader, satisfaction, and organizational citizenship behaviors. The Leadership Quarterly, 1(2), 107-142.

Polat, H. (2011). Türkiye ekonomisinde imalat sanayi. Dicle Üniversitesi İktisadi ve İdari Bilimler Fakültesi Dergisi, 1(2), 24-39.

Saunders, M., Lewis, P. ve Thornhill, A. (2009). Research methods for business students. 5th ed., Prentice Hall and an imprint of Pearson Education, Harlow.

TÜIK (2019). İstihdam edilenlerin ıktisadi faaliyet kolları (NACE Rev.2 15.01.2020 tarihinde http://www.tuik.gov.tr/PreTablo.do?alt id=1007 adresinden erişilmiştir.

Wan Zakaria, Z. W. ve Ilias, N. (2016). The impact of accounting system on the organisational performance: Evidence from Malaysian Government agencies. Journal of Global Business and Social Entrepreneurship, 2(5), 1-11.

Yavas, U. ve Yasin, M. M. (2001). Enhancing organizational performance in banks: A systematic approach. Journal of Services Marketing, 15(6), 444-453. 


\section{Kaynakça Bilgisi / Citation Information}

Küçükaltan, B. ve Mert, G. (2020). Örgütlerde dönüşümcü liderlik ve performans ilişkisinin değişim mühendisliği aracı rolünde incelenmesi: İmalat sanayii örneği. OPUS-Uluslararası Toplum Araştırmaları Dergisi, 15(10. Yıl Özel Sayıs1), 5065-5095. DOI: 10.26466/opus.684573 